\title{
- Note - \\ Survey of Marker Genes in the 9 Rat Strains
}

\author{
Michiru MIZUNO* and Kiyoshi SUZUKI** \\ * Shizuoka Laboratory Animal Agricultural Cooperative \\ Association, Koike-cho, 1616, Hamamatsu, 435, and \\ ** Institute of Medical Science, Tokyo University, \\ Shirogane-dai, 4-6-2, Tokyo, 108.
}

(Received for publication: Aug. 22, 1977)

In total of 17 genetic traits of the 9 strains of rats, Rattus norvegicus, examined, 9 loci showed polymorphic, being $a, c, d, h, E s-1, E s-2, E s-3, A m y-1$ and sex-influenced esterase $(d$-allele is not identified [12]. These genetic markers are not only useful as linkage markers but also available for inspection of proper meintenance of inbred rat strains.

\section{9 系統ラットにおける標識遺伝子の検索}

\author{
水野 充*・鈴木 潔** \\ * 静岡県実験動物農業協同組合 \\ ** 東京大学医科学研究所実験動物研究施設
}

近交系マウス・ラットの遗伝的斉一性および各系統間 の遺伝的差異を認識するためには，毛色遺伝子や形態的 な形質を支配する遺伝子の把握, 系統内あるいは系統間 皮唐移植や各系統の量的・質的形質の調査などの方法が 揭げられる。我々は既に近交系マウスの遺伝的斉一性の 問題について，特に電気泳動法を用いて検出される生化 学的形質を支配寸る遗伝子(以下生化学的遗伝子と略記) を標識として利用し，これらを適用することの長所とそ の重要性を示唆してきた $[5,7]$ 。今回我々は 9 系統のラ ットについて, 毛色および生化学的遗伝子の検索を行い, 得られた知見と共にその結果を報告する。

〔調査した系統拉よで遺伝子座位〕

使用した系統ラットは, 国立遗伝学研究所より購入し た ACI/N, Baffalo, Fischer 344, Long Evans, Wistar King-A の 5 系統, 和歌山県立医科大学上り 譲渡された Tester Moriyama, および東京大学医科 学研究所で維持されている LEW, JAR, Sprague Da- wley の 3 系統, 合計 9 系統である。これらの系統の由 来や世代数は『実験動物の系統維持・開発とその発がん 特性』研究班で維持しているがん研究用実験動物（昭和 51 年度, 研究代表者川俣順一) に詳しい。

有色ラットについては，その毛色によって $a, b, c, d$, $h$, の各座位の遺伝子型を推定し, アルビノラットにつ いては, Tester Moriyama (毛色遗伝子 a $a B B C C d d$. $h h$ ，但しこの $d$ 遗伝子については未確認 [12]）と交配 することにより， $a, d, h$ の各毛色座位を調査した。

生化学的変異については系統間に变異のあることが知 られている血清 esterase-1 (遺伝子座位記号 $E s-1$, 以 下同様) [1], 血清 esterase-2 (Es-2) [4,8], 小腸 esterase $(E s-3)[9]$, 腎臟 esterase $(E s-4)[10] お$ よび sex-influenced esterase [4] の各座位について 調査した。更に唾液および粹臟 amylase, 肝臓 isocitrate dehydrogenase (IDH), 腎臟 glucose-6-phosphate dehydrogenase (G6PDH), 腎臓 lactate deh- 
Table 1. Methods for Detection of Biochemical Traits

\begin{tabular}{|c|c|c|c|c|}
\hline Protein & Buffer system & Substate & Coenzyme & Dye \\
\hline esterases & $\begin{array}{l}\text { Tris-EDTA-Borate } \\
(\mathrm{pH} 8.6)\end{array}$ & B-naphtylacetate & - & Fast Blue BB Salt \\
\hline amylases & $\begin{array}{l}\text { Veronal-Na. veronal } \\
\qquad(\mathrm{pH} 8.6)\end{array}$ & $\alpha$-starch & - & $\mathrm{I}_{2}-\mathrm{KI}$ \\
\hline IDH & Tris-Citrate $\quad(\mathrm{pH} 7.0)$ & $\mathrm{Na}_{3}$. isocitrate & NADP & NBT **, PMS ** \\
\hline G6PDH & $\begin{array}{c}\text { Tris-EDTA-Borate } \\
\left(\mathrm{pH} \mathrm{8}^{8} .6\right)\end{array}$ & $\underset{\text { phosphate }}{\mathrm{Na}_{2} \cdot \text { glucose-6- }}$ & NADP & NBT **, PMS ** \\
\hline LDH & $\begin{array}{l}\text { Tris-EDTA-Borate } \\
\qquad(\mathrm{pH} 8.6)\end{array}$ & Na. lactate & NAD & NBT *, PMS ** \\
\hline catalase & Borate- $\mathrm{NaOH} /$ Tris-Citrate & $\mathrm{H}_{2} \mathrm{O}_{2}$ & - & $\mathrm{FeCl}_{3}-\mathrm{K}_{3} \mathrm{Fe}(\mathrm{CN})_{6}$ \\
\hline albumin & Na. acetate-EDTA & - & - & Amido Black $10 \mathrm{~B}$ \\
\hline transferrin & Borate- $\mathrm{NaOH} /$ Tris-Citrate & - & - & Amido Black $10 \mathrm{~B}$ \\
\hline
\end{tabular}

* Nitro Blue Tetrazolium

** Phenazine Methosulfate

Table 2. The Distributions of Alleles at 5 Coat Colour Genes and Several Biochemical Variants in the 9 Strains of Rats

\begin{tabular}{|c|c|c|c|c|c|c|c|c|}
\hline \multirow[b]{2}{*}{ Strain } & \multirow{2}{*}{$\begin{array}{l}\text { Generations of } \\
\text { full-sib mating }\end{array}$} & \multirow[b]{2}{*}{ Coat Colour $* *$} & \multicolumn{6}{|c|}{ Biochemical variants ** } \\
\hline & & & 1 & 2 & 3 & 4 & 5 & 6 \\
\hline $\mathrm{ACI} / \mathrm{N}$ & $\mathrm{F} 74+32$ & $\mathrm{AABBCCDDh}^{i} \mathrm{~h}^{i}$ & $\mathrm{~b}$ & $\mathbf{a}$ & a & $\mathrm{b}$ & $\mathrm{b}$ & + \\
\hline Baffalo & F 69 & cc & $\mathbf{a}$ & a & a & b & $\mathbf{a}$ & - \\
\hline Fischer 344 & F 111 & cc & $\mathbf{a}$ & $\mathbf{a}$ & $\mathbf{a}$ & b & $\mathbf{a}$ & - \\
\hline JAR & F 32 & ccDDhh & $\mathbf{a}$ & $\mathbf{a}$ & $\mathbf{a}$ & $\mathrm{b}$ & $\mathbf{a}$ & - \\
\hline LEW & $\mathrm{F} ?+19$ & aa $\quad c D D h h$ & $\mathrm{~b}$ & a & a & $b$ & $\mathbf{a}$ & + \\
\hline Long Evans & $F ?+53$ & aa BB CCDDhh & $\mathrm{b}$ & $\mathbf{a}$ & a & b & $\mathbf{a}$ & + \\
\hline Sprague Dawley & F 19 & aa ccDDhh & $\mathrm{b}$ & d & c & b & b & + \\
\hline Tester Moriyama & $\mathrm{N} 9+\mathrm{F} 1+6+3$ & aa BBCCdd*hh & $\mathrm{b}$ & a & c & b & b & + \\
\hline Wistar King-A & $\mathrm{F} 148+54$ & cc & b & c & $\mathrm{b}$ & b & $\mathbf{a}$ & + \\
\hline
\end{tabular}

* $d$-allele is not determined [12].

** Marker genes and their linkage groups are, respectively : $a$ (LGIV), $b$ (LGII), $c$ (LGI), $d$ (-), $h$ (LGVI), $1 ; E s-1$ (LGV), $2 ; E s-2(\mathrm{LGV}), 3 ; E s-3(\mathrm{LGV}), 4 ; E s-4$ (LGV), $5 ; A m y-1$ (-), and $6 ;$ sex-influenced esterase (LGV).

ydrogenase (LDH), 腎臓catalase の各䤃素のアイソ ザイム, および albumin, transferrin の血清蛋白につ いても電気泳動的検索を行い, 系統間变異の有無を調査 した。上記の種々の酵素・蛋白の泳動条件等を Table 1 に示す。

[調査結果および考察]

まず毛色・䤃素および蛋白の変異についてみると，今 回の調查では新たに膆臓 amylase に系統間変異が見い 出され (遗伝子座位記号 $A m y-1$, 仮称), 更に Sprague Dawley および Tester Moriyama にEs-3 座位の
新たな対立遺伝子 $E s-3 \mathrm{c}$ (仮称) が発見された [6]。従 って全体としては $a, c, d, h, E s-1, E s-2, E s-3, A m y$ -1 および sex-influenced esteraseの 9 座位に系統間 変異が見られたことになる (Table 2)。又 Es-4 座位 は全ての系統で $E s-4 \mathrm{~b}$ 遺伝子に固定しており, 調査し たその他の酵素・蛋白にも多型は見られなかった。

この様に本調査では系統間変異を示した醉素・蛋白の 数は我々の予想以下であり, 既にマウスの系統間で多型 の知られている G6PDH，IDH などの酵素にも変異が 見られなかった。これらの原因としては，ひとつには調 
査系統数が少いことが考えられるけれども, ラットの由 来がマウスのそれに比べ狭いこと, 寸なわち起源となっ た gene pool が小さいことにも原因するのであろら。 一方, 最近 Eriksson ら [2] は二地域の野生ラット集 団などについて，調查した25の肝酵素を支配する座位の らち11座位に多型が見られたことを報告している。彼ら は更に近交系である Fischer (F110) で2つ, ACI (F 95）で3つの酵素を支配する座位がまだ分離しているこ とを観察している。

次に系統間の差異をみると, 調查した 9 系統のうち, $\mathrm{ACI} / \mathrm{N}$, Sprague Dawley, Tester Moriyama およ び Wistar King-A の 4 系統が特異的な遺伝子型のパ ターンを示したが, Baffalo, Fischer 344 と JAR, お よび LEW と Long Evans がそれぞれ同一のパター ンを示した。な挆調查時点では LEW, Sprague Dawley, Tester Moriyama の 3 系統がまだF20を越えて はいなかったが, これら 3 系統を含む全ての系統につい て，調査した毛色および生化学的遺伝子は各系統でそれ ぞれ固定しており, 交雑ミスなどが起った可能性はない と考えられる。

ラットの近交系は現在亜系を含め 100 系統ほど報告さ れている [3]が，実際に維持されている系統は更に多い であろう。これらの系統を見てみると, Wistar を由来 とする系統を始めとして同一 closed colony に由来す る系統が多いが，同じ系統名の亜系を遺伝的に同一視し て良いかどらかは現在問題となっている所である。更に 系統そのものの由来が不明瞭なものや, 標識遺伝子が記 載されていない系統もあり, 現在の系統ラットに関する 遺伝的斉一性の問題や, 系統同定の問題を複雑にしてい る。この原因としては,アルビノの系統が圧倒的に多い ので外観からは交雑ミスなどの有無の判断が不可能なこ とが多く, 又後代検定により毛色遗伝子を調査するにし ても, 西村が Tester Moriyamaを, 山田・中島 [12] が abh, bhd の 2 系のテスター系統を作出するまで, 優 れたテスター系統が見あたらなかったことなどが考えら れる。又ラット系統間に可視的な形質を支配する遺伝子 がそれほど知られていないことにも起因しているのかも 知れない。

各系統ラットの系統間の遺伝的差異を認識し, 更に各 系統の遺伝的チェックを行らために生化学的遺伝子を利 用することは重要である。今回調査した毛色および生化 学的標識遺伝子は少なくとも 4 染色体以上に位置してお り [11], 遺伝的チェックの観点からはある程度の効果 は期待できると考えられる。又これらの標識遺伝子は linkage marker としても有用である。今後は検索す べき蛋白酵素ならびに調査系統数も増やしてゆく予定で あるが, ラットの系統間にどの程度の遺伝的多様性が保 たれているのかも興味ある問題である。

[要約]

9 系統のラットについて, 毛色および生化学的変異を 支配する 17 座位を調査したところ， $a, c, d, h, E s-1$, $E s-2, E s-3, A m y-1$ および sex-influenced esterase の 9 座位に系統間変異が見られた。これらの標識遺伝子 は linkage marker として有効であるばかりでなく, 各系統の遺伝的斉一性のチェックをする場合にも利用で きる。

終りに当たり Tester Moriyama 系ラットを分与していた だいた和歌山県立医科大学西村正彦博士に深謝する。

\section{[文献]}

1. Augustinsson, K. B., and Henricson, B. (1966). A genetically controlled esterase in rat plasma. Biochem. Biophys. Acta $123: 323-331$.

2. Eriksson, K., Halkka, O., Lokki, J., and Saura, A. (1976). Enzyme polymorphism in feral, outbred and inbred rats (Rattus norvegicus). Heredity 37 : 341-349.

3. Festing, M., and Staats, J. (1973). Standardized nomenclature for inbred strains of rats. Fourth listing. Transplantation $16: 221-245$.

4. Gasser, D. L., Silvers, W. K., Reynolds, H. M., Black, G., and Palm, J. (1973). Serum esterase genetics in rats : two new alleles at $E s-2$, a new esterase regulated by hormonal factors, and linkage of these loci to the $\mathrm{Ag}-\mathrm{C}$ blood group locus. Biochem. Genet. $10: 207-217$.

5. 水野充・近藤恭司 (1976). NZB 系マウスの Es-1 遺伝子 座位に見られたへテロ性の研究, 実験動物, 25：291-295.

6. Mizuno, M., and Suzuki, K. (1978). Genetic variation of pancreatic $\alpha$-amylase in the rat, Rattus norvegicus. Jap. J. Genet. $53: 137-142$.

7. 水野充・鈴木潔・富田武・近藤恭司, (1977). 近交系マウス に扔ける生化学的標識遺伝子の重要性, 実験動物, $26: 43-49$.

8. Womack, J. E. (1972) Genetic control of the major electrophoretic component of rat plasma esterase. Heredity $63: 41-42$.

9. Womack, J. E. (1972). Genetic control of an ester ase of digestive tract tissues in Rattus norvegicus. Experimentia $28: 1372$.

10. Womack, J. E. (1973). Biochemical genetics of rat esterases : polymorphism, tissue expression, and linkage of four loci. Biochem. Genet. $9: 13-24$.

11. Womack, J. E., and Sharp, M. (1976). Comparative autosomal linkage in mammals : genetics of esterases in Mus musculus and Rattus norvegicus. Genet. 82 : 665-675.

12. 山田淳三・中島一男 (1976). 2 系統の毛色遺伝子テスト用 ラットの作出, 実験動物, $25: 307-308$. 